\title{
PHAGOCYTIC AND BACTERICIDAL ACTIVITIES OF PERITONEAL AND ALVEOLAR MACROPHAGES FROM MICE
}

\author{
M. Degré \\ Microbiological Laboratory, Ullevål Hospital, Oslo, Norway \\ Plate XXVII
}

MACROPHAges from different locations, such as the lung, the peritoneal cavity, or the liver, are considered to be essentially the same cell type. Recent work, however, has emphasised substantial differences between these cells in their bactericidal abilities (Pavillard and Rowley, 1962; Pavillard, 1963), their respiratory patterns (Oren et al., 1963), and their enzyme content (Myrvik, Leake and Fariss, 1961; Pavillard; Leake, Gonzales-Ojeda and Myrvik, 1964). Similar variations among individual cells within a large population have been demonstrated (Mackaness, 1960). These differences do not seem to be consistent in different animal species. Alveolar macrophages from rats have proved to have a higher content of acid phosphatase and lysozyme, but they are less actively bactericidal than peritoneal macrophages from the same animals (Pavillard). In the rabbit, alveolar macrophages were found to contain more lysozyme, acid phosphatase, and beta-glucuronidase, and they had a greater endogenous oxygen consumption than did oil-induced peritoneal macrophages; moreover, the alveolar macrophages seemed to be more active immunologically (Myrvik et al.; Leake et al.). Macrophages from different organs of the mouse differed in their morphological development and mitosis rates, but were similar in their ability to phagocytose particles and in their content of cytoplasmic acid phosphatase (Bennett, 1966). Recent technical advances make it possible to isolate phagocytic cells from mice and to grow them in practically pure culture. This is of interest in research work on infectious diseases and in studies on host resistance to infection in which mice are frequently employed. The object of the present study was to compare quantitatively the phagocytic and bactericidal activities of peritoneal and alveolar macrophages from mice in in-vitro systems.

\section{MATERIALS AND METHODS}

Mice of the HaM/ICR/CSE/Bom strain, obtained from the States Public Health Institute, Oslo, were employed. Male mice, 3-5 mth old, weighing 22-28 g, were used because the macrophages obtained from this group were relatively numerous and pure.

Test organism. Haemophilus influenzae b 51, originally from H. C. Engbaek, Copenhagen, was kindly provided by Dr T. Omland. The strain was used after 42 passages on solid medium. A large number of samples, $c .1 \mathrm{ml}$ each, were frozen in Levinthal broth. For phagocytosis experiments a sample was incubated in $5 \mathrm{ml}$ Levinthal broth for $18 \mathrm{hr}$ at $37^{\circ} \mathrm{C}$, then centrifuged at 3500 r.p.m. for $10 \mathrm{~min}$. and reconstituted in physiological saline.

Procedure for harvesting macrophages. Hanks' balanced salt solution (BSS), containing 1 per cent. ethylene diamino tetra-acetic acid dipotassium salt (EDTA), and 0.5 IU of heparin per $\mathrm{ml}$, was used to wash out both peritoneal and alveolar macrophages. Mice were killed by cervical fracture. Peritoneal macrophages were obtained by a modification of the method described by Whitby and Rowley (1959). The skin over the abdominal region was removed and $3 \mathrm{ml}$ of the washing fluid was forced into the peritoneum with a hypodermic needle. After light massage for a few seconds, fluid was withdrawn from the lateral part of the peritoneal cavity. Usually about $2 \mathrm{ml}$ fluid could be obtained from each mouse. Alveolar macrophages were obtained by a modification of the method described by Russell and Roser (1966). The anterior chest wall and pretracheal muscles were dissected away. A 14-gauge needle was forced into the trachea just below the larynx. One $\mathrm{ml}$ of the 
washing fluid was forced into the lung and withdrawn after a few seconds without massage of the lungs. The washing was repeated twice. Cell suspensions from 5-7 mice were pooled, centrifuged at 600 r.p.m. for $10 \mathrm{~min}$., and resuspended in an appropriate volume of EagleHanks' Minimum Essential Medium (MEM). In all comparative experiments, cells from the same animals were used. Samples macroscopically contaminated with red blood cells were discarded.

Cell counts. Wet preparations were counted in a Bürker chamber. Preparations for differential counts and studies of cellular morphology were stained with Wright's stain. Viability of cells was ascertained by staining with trypan blue.

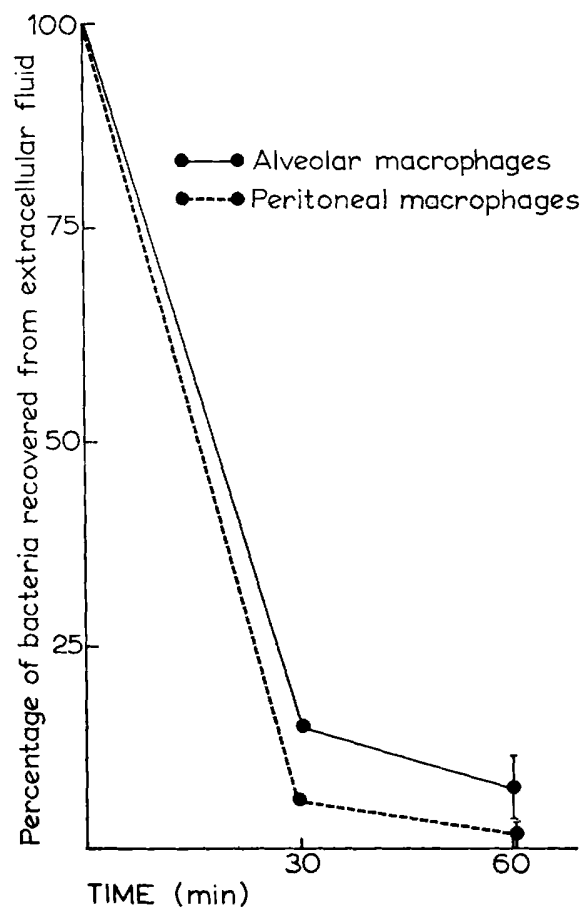

FIG. 1.-Phagocytosis of Haemophilus influenzae by peritoneal and alveolar macrophages in suspension. Vertical bars indicate standard deviation.

Phagocytosis in suspension. The procedure used was similar in essentials to the method described by Cohn and Morse (1959). Cells were dispersed into tubes of $10 \times 70 \mathrm{~mm}$. Each tube contained $c$. (1-5) $\times 10^{5}$ macrophages in Eagle-Hanks' MEM at $p \mathrm{H} 7 \cdot 2$ with 20 per cent. normal mouse serum. Bacteria were added in a ratio of about 5-20 bacteria per macrophage. The total volume in each tube was $1 \mathrm{ml}$. Control tubes without cells were included in each experiment. The tubes were incubated at $37^{\circ} \mathrm{C}$ with end-over-end mixing at 40 r.p.m. At 30 and 60 min., samples were removed and the surviving bacteria were counted. Extracellular bacteria were enumerated by plating appropriate dilutions from the supernatant after differential centrifugation at 600 r.p.m. for 6 min. Total viable bacteria were enumerated after lysing the macrophages with 5 per cent. saponin for $15 \mathrm{~min}$. at room temperature; the bacteria were then counted by culturing appropriate dilutions on plates.

Phagocytosis by monolayers of macrophages. The method employed was similar to that described by Whitby and Rowley and by Pavillard. Washed cell suspensions containing c. $10^{5}$ macrophages were pipetted into Leighton tubes in which a "flying coverslip " covered the entire bottom surface. Normal mouse serum was added to make a final 20 per cent. 
concentration. The mixtures were incubated at $37^{\circ} \mathrm{C}$ for $18 \mathrm{hr}$. Then the coverslips were removed aseptically, washed gently with physiological saline and placed into fresh sterile Leighton tubes. After such treatment the macrophages were attached to the surface of the glass coverslips; other cell types were dead or had been washed off. Bacterial suspension in Eagle-Hanks' MEM at $p \mathrm{H} 7 \cdot 2$ was added to make a final ratio of $c .100$ macrophages per bacterium. Normal mouse serum was added to each tube in a final concentration of 20 per cent. The total volume was $1 \mathrm{ml}$. The tubes were incubated stationary for $1 \mathrm{hr}$ and the surviving bacteria were then enumerated. Supernatant fluid was removed and plated in appropriate dilutions. The coverslips with the macrophage monolayers were also removed

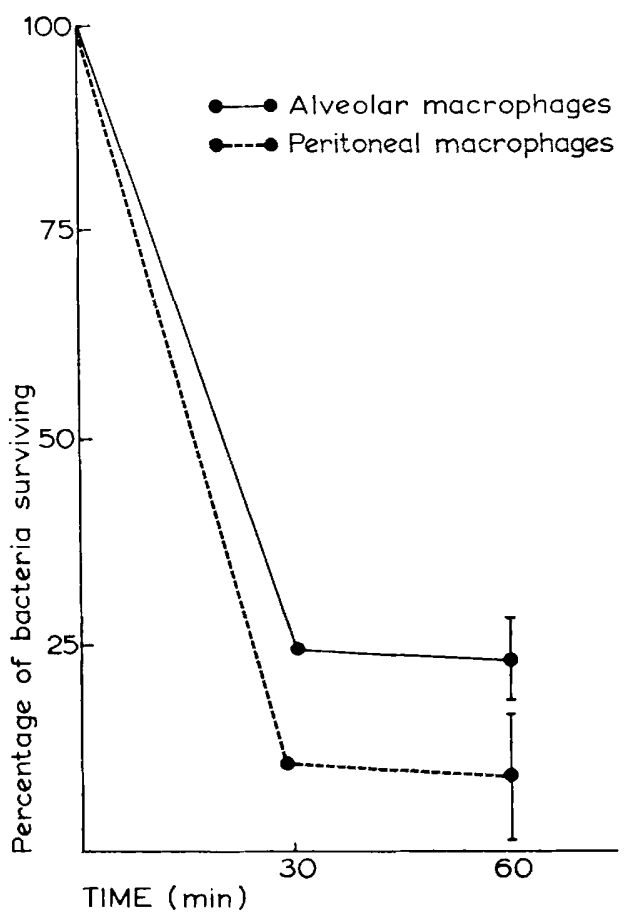

FIG. 2.-Bactericidal effect of peritoneal and alveolar macrophages in suspension on Haemophilus influenzae. Vertical bars indicate standard deviation.

and washed gently three times with physiological saline in order to remove bacteria not closely associated with the cells. A few drops of 5 per cent. saponin were pipetted on to the coverslips. After a few minutes the coverslips were inverted and rubbed on to the surface of agar media to dislodge any macrophages and bacteria that were still attached to the surface. Colony counting was done after incubation for $18 \mathrm{hr}$ at $37^{\circ} \mathrm{C}$.

The difference in numbers of bacteria recovered from test series and control series was attributed to the influence of the phagocytic cells. The function of these cells was further classified into phagocytic action and intracellular killing as indicated by the difference in numbers of bacteria recovered from the extracellular fluid and from the lysed phagocytic cells.

\section{RESULTS}

Wash-out fluids from the peritoneum and from the lung contained 85-95 per cent. mononuclear cells, 90-95 per cent. of which were viable. The possible phagocytic component of polymorphonuclear cells was therefore negligible. 
The results of interaction between macrophages and Haemophilus influenzae in suspension are shown in figs. 1 and 2. Each figure represents the mean of 6 experiments. Both peritoneal and alveolar macrophages were phagocytic and bactericidal. The phagocytic effect of peritoneal macrophages seems to be more efficient, 98.2 per cent. of the bacteria being removed from the extracellular fluid after $1 \mathrm{hr}$; the corresponding figure for the alveolar macrophages is 92.8 per cent. However, the difference is not significant, and the tendency is not consistent. The difference in bactericidal ability seems to be more marked. Peritoneal macrophages killed 90.8 per cent. of the $H$. influenzae population in $1 \mathrm{hr}$, whereas the alveolar macrophages killed 76.8 per cent. Intracellular survival of bacteria was 7.4 per cent. in peritoneal macrophages and 16 per cent. in alveolar macrophages after $1 \mathrm{hr}$. Peritoneal macrophages were more efficient in every experiment performed.

TABLE

Phagocytosis and intracellular killing of Haemophilus influenzae by monolayers of peritoneal and alveolar macrophages

\begin{tabular}{|c|c|c|c|c|c|c|}
\hline \multirow{3}{*}{$\begin{array}{l}\text { Test bacteria in the } \\
\text { presence of }\end{array}$} & \multicolumn{4}{|c|}{ Bacteria recovered from } & \multirow{2}{*}{\multicolumn{2}{|c|}{$\begin{array}{l}\text { Total number of } \\
\text { bacteria recovered }\end{array}$}} \\
\hline & \multicolumn{2}{|c|}{ extracellular fluid } & \multicolumn{2}{|c|}{ macrophages } & & \\
\hline & Number & Per cent.* & Number & Per cent.* & Number & Per cent.* \\
\hline Peritoneal macrophages. & $3 \cdot 10 \times 10^{3}$ & $67 \cdot 3$ & $7 \cdot 0 \times 10$ & $1 \cdot 6$ & $3 \cdot 17 \times 10^{3}$ & $68 \cdot 9$ \\
\hline Alveolar macrophages . & $3.20 \times 10^{3}$ & $68 \cdot 9$ & $5.9 \times 10^{2}$ & $12 \cdot 8$ & $3.79 \times 10^{3}$ & $82 \cdot 3$ \\
\hline Control (no macrophages) & $\ldots$ & $\ldots$ & $\ldots$ & $\ldots$ & $4.60 \times 10^{3}$ & 100 \\
\hline
\end{tabular}

* Number expressed as percentage of estimated total test population.

Macrophages derived from the different sites and cultured on glass surfaces developed different morphological appearances (figs. 3 and 4). Alveolar macrophages remained unchanged, round, with only a slight tendency to assume the fibroblastic form that was regularly seen with peritoneal macrophages after a few hours' incubation. The phagocytic and bactericidal efficiency of these cells cultured on coverslips was less than that of cells in suspension. The peritoneal macrophages were again superior to the alveolar cells in all experiments performed, especially in their bactericidal ability; the difference was more marked when the tests were done with cells in monolayers on coverslips than in experiments with cells in suspension. The results of a representative experiment are shown in the table.

\section{DisCUSSION}

In these comparative experiments special care was taken to exclude variations not attributable to differences in the phagocytic cells. Macrophages were isolated from identical animals in each parallel experiment to eliminate variation from one individual to another. The method of isolation of the cells from the lung and from the peritoneum, and the preparation of the cells for the phagocytic experiments were practically identical. None of the cells was preconditioned by exposure to evoking agents. It is therefore reasonable to assume that cells from the different origins were in the same condition at the time of the experiments. Both cell preparations were treated identically under the phagocytic process. The different rates of disappearance of viable bacteria from the test culture population were therefore attributed to differences in the phagocytic and bactericidal activities of the macrophages. 
ACTIVITIES OF MOUSE MACROPHAGES

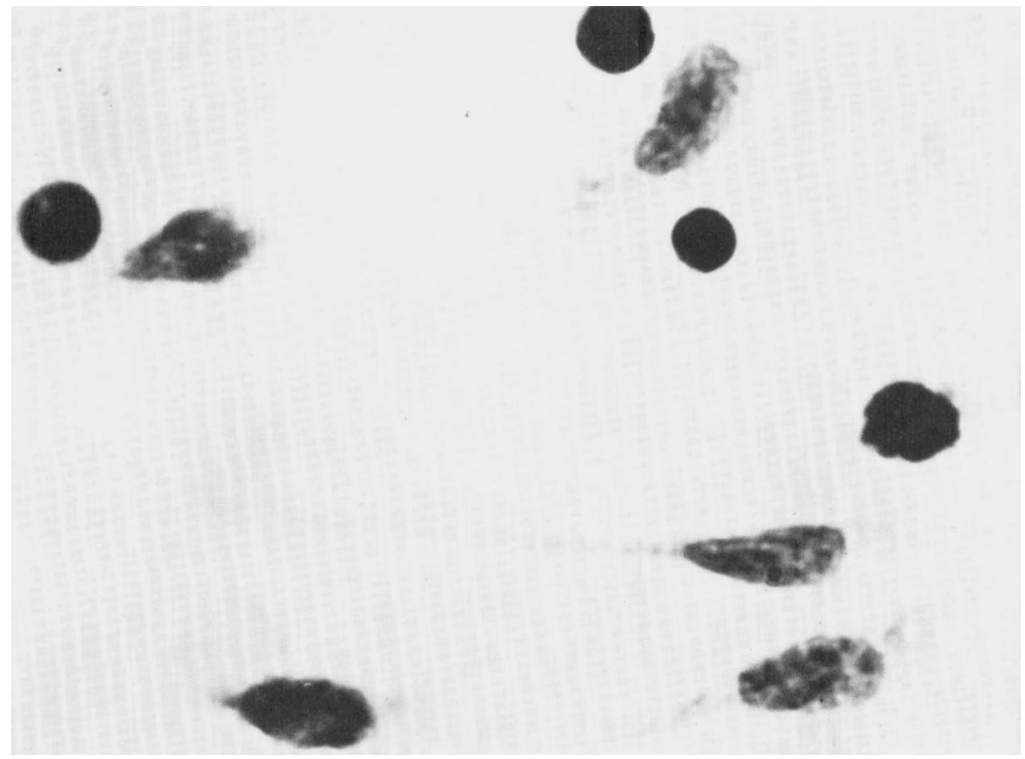

FIG. 3.-Coverslip preparation of peritoneal macrophages after cultivation for $4 \mathrm{hr}$. Wright's stain. $\times \mathbf{4 0 0}$.

FIG. 4.-Coverslip preparation of alveolar macrophages after cultivation for $6 \mathrm{hr}$. Wright's stain. $\times 400$. 
The results of the experiments presented here seem to indicate that macrophages from different organs of the mouse differ in their interaction with bacteria. The bactericidal effect of macrophages from the peritoneal cavity seems to be stronger than that of alveolar macrophages. Although a similar pattern was found when comparing the phagocytic activities, the difference was not significant.

These findings are similar to those reported for rat macrophages by a directly comparable method (Pavillard, 1963). The difference between mouse peritoneal and alveolar macrophages seems to be smaller in the present study. However, the different bacterial species employed may be of significance in this respect (Rowley and Whitby, 1959; Whitby and Rowley, 1959).

The change in morphology of alveolar and peritoneal macrophages that developed during culture on glass surfaces was practically the same as that demonstrated with macrophages from different animal species by Pavillard and Rowley (1962) and by Bennett (1966). This tendency to form a characteristic fibroblastic appearance during culture on glass might be consistently associated with greater phagocytic and especially with greater bactericidal activity of the cells; in the present study, the peritoneal macrophages had a much greater tendency to assume the fibroblastic form than did the alveolar macrophages, and the peritoneal cells were then more actively phagocytic and much more actively bactericidal than the alveolar cells. Other parameters such as metabolic activity and enzyme content, referred to in earlier studies, might vary independently of those functions.

The present findings indicate that macrophages from peritoneum and lung behave differently. Apart from the theoretical interest of this observation, a practical point is that although peritoneal macrophages can be obtained more easily and in much greater numbers than alveolar macrophages, they cannot now be regarded as identical cells for in-vitro experiments.

\section{SUMMARY}

A comparison was made of the in-vitro phagocytic and bactericidal activities of mouse macrophages derived from the peritoneal cavity and from the lung. Both cell types were active, but peritoneal macrophages were superior, especially in their bactericidal ability. The two cell types also showed morphological differences when cultured on glass surfaces. The results are compared with those of similar studies of macrophages derived from other animal species.

I wish to acknowledge with thanks the support given by the Norwegian Pasteur Legat and Homan Minde's Legat.

\section{REFERENCES}

BENNETT, B.

COHN, Z. A., AND Morse, S. I.

LEAKE, Eva S., GONZALEs-OJEDA,

DOLORES, AND MYrVIK, Q. N.

MACKANESS, G. B.

MYRVIK, Q. N., LeAKe, Eva S., AND FARISS, B.

Oren, Rachel, Farnham, AnN E., 1963. J. Cell Biol., 17, 487. SAITO, K., Milofsky, EVA, AND KARNOVSKY, M. L.

Pavillard, E. R. J.

Pavillard, E. R. J., AND Rowley, D. .

ROWLEY, D., AND WhitBY, J. L.

Russell, P., AND ROSER, B. .

WhITBY, J. L., AND ROWLEY, D.
1966. Amer. J. Path., 48, 165.

1959. J. Exp. Med., 110, 419.

1964. Expl Cell Res., 33, 553.

1960. J. Exp. Med., 112, 35.

1961. J. Immun., 86, 133.

1963. Austral. J. Exp. Biol. Med. Sci., 41, 265. 1962. Ibid., 40, 207.

1959. Br. J. Exp. Path., 40, 507.

1966. Austral. J. Exp. Biol. Med. Sci., 44, 629.

1959. Br.J. Exp. Path., 40, 358. 